\title{
Social Base of Relationship between Religious Groups in West Manggarai District, East Nusa Tenggara Province
}

\author{
Yustinus Suhardi Ruman
}

\begin{abstract}
In an increasingly knowledge-based society, social cohesion can be built through government policy, such as open access to the similar resources required for all groups. Reflecting on the setting, this study emphasizes the social resources that exist within the community itself. In this sense, it referred to kinship relations between the two religious' groups, namely Catholicism and Islam. By using a qualitative approach and the concept of social cohesion, this study found that the two religious groups who are living together as one community in the inland or rural in West Manggarai district have the same family background. In consequence, the social obligations that they receive solely based on it, regardless of religious differences. This study, therefore, concluded that the background of the same family relationships contributes to creating social cohesion in society.
\end{abstract}

Index Terms: social, cohesion, Catholic, Muslims

\section{INTRODUCTION}

The composition of the population, based on religion in Indonesia, shows that Islam is the majority. The other majority population is Protestant, Catholic, Hindu and Buddhist, respectively. Confucian religion ranks the last.

Nationally, the relationship between religions in Indonesia runs harmoniously. Conflicts between religious believers nationwide never happened. Conflicts based on religious identity usually only occurs locally as happened in Ambon, Poso, Bali, Kalimantan, Papua and some other areas.

Nonetheless, social conflicts based on religious identity as occurred in these areas is not a common occurrence in all areas at the local level in Indonesia. Many areas at the local level in Indonesia has a harmonious relationship between the groups, including, in this case, is the relationship between religious groups. One example is the relationship between religious groups in the East Nusa Tenggara, one of the provinces of Indonesia. East Nusa Tenggara is a province whose majority are Catholic. The next majority population is Protestant, and then Hinduism, Buddhism, the last is Confucianism.

The relationship between religious groups in East Nusa Tenggara is very harmonious. Therefore, the central government put a monument of the gong of peace in East Nusa Tenggara. In 2011, the President of Indonesia, Susilo Bambang Yudhoyono inaugurated the peace gong. Peace Gong is a symbol of social movements from all groups of

Revised Manuscript Received on April 19, 2019.

Yustinus Suhardi Ruman, Character Building Development Center,

Mass Communication Program, Communication Department, Faculty of Economics \& Communication, Bina Nusantara University, Jakarta, Indonesia.(Email: yruman@binus.edu) any social background to always put peace above the interests of the group.

This study explains the rationality why the relationship between religious groups in East Nusa Tenggara province can run in harmony. The field of this research is West Manggarai regency, which is one of the districts in the East Nusa Tenggara Province. This study describes the social base of the relationship between religious groups in West Manggarai. The main research question is, what is the social base of the relationship between religious groups in West Manggarai Regency?

\section{THEORETICAL FRAMEWORK}

\section{A. Social Group Definition}

Social groups are defined as two or more people who have the same identities and interact regularly. According to Charles Horton, there are two types of groups: primary and secondary groups. The relationship among members of the primary group is personal. In these groups, every person has strong personal loyalty and eternal. Primary Group member specifically does activities together and spends time together, so they get to know each other better. They were taking care of one another. The family is the primary group that is very important in any society [1].

Primary groups are also central to the construction of social identity. In a relationship or everyday social interaction, they feel comfortable and safe. The members of the primary group provide various benefits for the other members, including financial and emotional support. In principle, the primary group is a destination. In this line, this primary group is not a tool to achieve social objectives. In this context, if every member of mutual help to each other, the action was based not on profit.

The second type of group is called the secondary group. A secondary group is defined as something that is specifically social relations between its members and the wider impersonal. Therefore, members of the second group do not have relationships that are emotional. The relationship between them is based on the relationship of interest. This group will disband when the interests of its members are not being met.

Durkheim [2] distinguishes social groups based on the level of solidarity. Based on solidarity, social groups consisting of social groups that are based on mechanical 
solidarity and social groups based on organic solidarity. Mechanical solidarity based on a shared collective consciousness that refers to the totality of beliefs and sentiments shared that on average, there are villagers in the same. It is a solidarity that relies on individuals who have the same properties, conscience and religion and the same normative pattern anyway. An essential characteristic of mechanical solidarity is that solidarity is grounded in a high degree of homogeneity in the trust, sentiment, and so on. Homogeneity usually occurs in conditions of the division of labour in society was minimal.

Organic solidarity, on the contrary, is growing because of the high division of labour. This kind of solidarity is based on a high degree of interdependence. This dependence arises because of growing specialization. The relationship between members in mechanical solidarity is functional. If group members do not perform any function or role, then, the group on mechanical solidarity will end

\section{B. The Concept of Social Cohesion}

The term "social cohesion" means the state of a society, group or organization where solidarity is strong and intense social ties [3]. According to Lahmar, social cohesion promotes the integration of people, their commitment to the group and their participation in social life. Members share a common set of values and rules of conduct that are accepted by everyone.

Woolley and Jenson (1998) as cited by Berger-Schmitt [4] stated that that the aspects often mentioned in describing social cohesion are the strength of social relations, shared values and communities of interpretation, feelings of a common identity and a sense of belonging to the same community, trust among societal members as well as the extent of inequality and disparities.

Theoretically, the concept of social cohesion rooted in the work of Durkheim [5]. In His Book the Division of Labor in Society, Durkheim introduced the basis of society. According to Durkheim, the basis of every society is solidarity. In the traditional community, the solidarity based on common conscience that is the totality of beliefs and sentiments common to average citizens of the same society forms a determinate system which has its own life. However, in modern society, solidarity is built on contractual relationships which determine social order.

Social cohesion is influenced by several factors. Some of the factors are structured, such as income inequality, wealth inequality, and socioeconomic disadvantages and cultural, ethnic, linguistic and religious diversity are viewed as some important factors contributing to social cohesion. The second strand of literature discusses the economic and developmental implications of social cohesion [6].

Moreover, social cohesion is also depending on the country's policy. A Country with a high degree of inclusion tends to have good social cohesion. As stated by Easterly Ritzan, Woolcock [7], the inclusiveness of a country's communities and institutions (e.g., laws and norms against discrimination) can greatly help to build cohesion. On the other hand, countries strongly divided along with class and ethnic lines will place severe constraints on the attempts of even the boldest, civic-minded, and well-informed politician (or interest group) seeking to bring about policy reform.
Social cohesion is essential for the resilience of a community. Studies of Stephen Knack and Philip Keefer [1997) in the economic field, as cited by McCracken [8] showed that social cohesion could improve economic performance, such as reduced transaction cost, increased investment ratio and encouraged the innovation. Furthermore, it makes better performance of government institutions in the provision of public goods and policy. Related to the economic growth, other studies also showed that, social cohesion facilitates the collective action that is cooperation among individuals (or group) in pursuit of economic benefit.

This article does not explain the benefits of social cohesion between groups, but only describes the foundation of social cohesion between groups. Its focus is on social cohesion between religious groups in West Manggarai, Flores, East Nusa Tenggara. Religion is one important factor in creating social integration. Religious symbols can reinforce a sense of unity in religious groups, and religious rites create a sense of unity by allowing members to participate symbolically with a broader unity. Durkheim in Schaefer, [9] sees religion as an integrative force in human society.

Durkheim tried to answer questions arise, how a society can be run together when they are formed by individuals and social groups with different interests and aspirations? In his view, religion is often beyond the powers of personal and divisive. How can religion become a unifying community? Religion is the Buddhist, Muslim, Christian or Jewish, said Durkheim gives meaning and purpose to human life.

Religion offers the core and terminal values that are believed together. Although these values are subjective and not always accepted in full, these values help the community as a social system integrated.

Durkheim explained the internal social cohesion in each group. This view does not explain the social cohesion between different groups, such as social cohesion among religious groups. To explain the social cohesion between religious groups, this article uses the concept of kinship with the assumption that kinship is an important variable in shaping social cohesion between religious groups.

\section{RESEARCH METHODS}

The qualitative based-research serves as the method to describe the foundation of social cohesion between religious groups in West Manggarai. The researcher collects data through in-depth interview and observation. The subjects that will be the informant are public figures from both the Catholic and Muslims religious groups.

This study will be conducted in West Manggarai, Flores, and East Nusa Tenggara. Based on the knowledge and experience of researchers to interact with citizens in the West Manggarai, the researcher tentatively concluded that there had not been a conflict between religious groups in West Manggarai district in general and between Catholics and Islam in particular. These phenomena are interested if we compare with the social conflict based on religious issue in Indonesia generally. 


\section{DISCUSSION}

Top of Form

The relationship between religious believers in general and among adherents of Islam and Catholicism in West Manggarai regency until now runs harmoniously. This can be explained by the evidence of cooperation among religious adherents in various social, cultural and religious events. However, in the first, the researcher describes the character and the background of adherents of Islam in West Manggarai and then explains how the social cohesion between religious groups has been formed in society.

The adherents of Islam in West Manggarai can be categorized into two types: those who live in coastal areas and inland/rural. Muslim populations who live in coastal areas come from other islands such as Sumbawa and Sulawesi are fishermen. They came and settled along with the coastal areas in both the northern and southern part of West Manggarai for fishing. They settled in this area all the time. They built houses and formed a homogeneous social life. All of them are adherents of Islam with the primary means of livelihood as a fisherman.

In contrast to that settled in the coastal areas, the adherent of Muslim who settled in the inland or rural is more heterogeneous. They lived among the adherent of Catholics as the majority of citizens. The two groups lived together to form a unified community. To explain how the two groups can coexist to form a complete community, the researcher tries to describe historically and culturally the background of the adherent of Islam who settled in these areas.

Historically, the adherent of Muslim who lived in the inland or rural area can be connected with the exploitation of Sulawesi and Bima sultanate on Manggarai. As generally known, the Manggarai is one region that was dominated by the Sultanate of Goa in Sulawesi and then by Sultanate of Bima approximate in the 17th century. Both of the empires are Muslims

As a colony, the people of Manggarai paid taxes to both the empire. At any certain time, officers or delegates of Sultan came to collect taxes. The tax officials are all Muslims. Therefore, because they are Muslims, then they must also be served by people who are Muslims like to cut Beef, Chicken, or Goat.

Generally, the indigenous people of Manggarai are not Muslim. So, to service the nobles or officers who came to collect the taxes, the indigenous community did not only provide sacrificial animals, but also the people of Islam to cut them. Therefore, the Indigenous community allowed some of the member of community to be a Muslim. So that, whenever the nobles came, they were served by the Muslims that exist in every community at Manggarai.

Until now, they are still a Muslim. Most of them have been performing Hajj. Based on the history, the groups of Muslims who settled in the inland or rural of Manggarai generally or West Manggarai came from the same lineage. It means that social interaction among villagers is based on family relationships. Thus, the first preference in their everyday social relations is family. They feel like one family. As a family, each member will participate in various social events that they face. They participate in helping

family members who are having difficulties such as death, marriage or religious celebrations.

Their participation in the various and whole social, cultural, and religious event is not based on their special identity as a Muslim or Catholics, but solely because they have - as Durkheim stated - a 'common conscience' as a member of the same family, although they aware of their special identity as Muslim or Catholics. All the local community at West Manggarai generally consists of these two groups of religion. The composition of these groups is Catholics as majority and Muslim minority.

Although the Catholic religion is the majority population in any community, the relationship between these two religious' groups in everyday life is running in harmony. They support each other without regard to their specific identity as members of a religious group. For instance, when Catholics celebrate Christmas or Easter, the adherent of Islam will participate in various activities such as security, providing the tents to celebrate or cleaning the place of worship. Conversely, if the Moslems celebrate the Aidil Fitri, Catholics participate in supporting the celebration.

Socially and culturally, mutual support and participation can be seen in several social and cultural events. If one of the families is experiencing grief due to death, another family will come to help them. Likewise, if one family marries members of their families, other families will come to support them. This is also in the cultivation process of agricultural land; each family helps each other.

In short, they each receive their religious identity, as well as differences in other social identities as men and women, parents and children, leaders and members. The differences in social identity do not diminish their participation in social life every day. Their participation in this context is experienced as a social and moral obligation. This obligation cannot be explained from their religion identity background but exactly based on a feeling of togetherness in the context of kinship relation.

Many adherents of Islam of Inland or rural now become a leader of Islam religious group throughout of West Manggarai regency. They are influential Islamic leaders. Their presence, role and their moral status as Hajj help to strengthen the cohesiveness of relations between adherents of Islam and Catholicism in West Manggarai.

Based on the view of Weber [10] about an open relationship, the relation between Muslim and Catholic is much opened. According to Weber, a social relationship can be said as open if participation mutually oriented social action relevant to its subjective meaning is, according to its system of order, not denied to anyone who wishes to participate and who is actually in a position to do so. Weber stated that whether a relation open or closed may be determined traditionally, effectually, or rationally in terms of values or of expediency. In the context of Weber, the openness relation among adherent of religion in West Manggarai regency can be explained traditionally from the background of their kinship relation. 


\section{CONCLUSION}

Top of Form

Based on the phenomena that occurred in the community of West Manggarai Regency as described above, the relationship between religious or cooperation between religions is not only based on their understanding of abstract between faiths. The abstract notion was usually built based on the theological explanation, the biblical and philosophical.

Theologically example explained that every human being is God's creation. Therefore, every human being must be treated with respect as fellow creatures. The biblical explanation is usually based on the verses that advocate for mutual respect between people of any religion. While the philosophical explanation is usually based on the nature of the common humanity of all people, whatever their social background, including, in this case, is the religious background.

Based on these explanations, everyone is encouraged to do the same work, tolerance and build solidarity regardless of their social or religious. Social phenomena on the relationship between Muslim and Catholic right as described above in the case of West Manggarai regency showed that the basis of social interaction, solidarity, tolerance is not only built on the interrelatedness of understanding that is abstract but sociologically based on the kinship relation.

Theoretically, the relationship between Catholics with adherents of Islam in West Manggarai regency has its unique characteristics, mainly because it is a cultural relationship based on family relationships. Moreover, the relationship between Catholics with adherents of Islam in West Manggarai regency it departs from the same social base and the relationship between family members.

\section{REFERENCES}

1. Macionis JJ. Sociology (14th ed.). 2012;

2. Johnson DP. Teori Sosiologi Klasik dan Modern. Jakarta: PT.Gramedia; 1998.

3. Lahmar H. Social Cohesion : Identification of Parameters Measurement. 2015;3(1):90-2.

4. Regina Berger-Schmitt. Social Cohesion as an Aspect of the Quality of Societies: Concept and Measurement. Eureporting Work Pap No 14. 2000;1-31.

5. Durkheim E. The division of labour in society. Social Theory Re-Wired: New Connections to Classical and Contemporary Perspectives: Second Edition. 2016. 16-39 p.

6. Ncba E. Working Paper Diversity, Inclusiveness and Social Cohesion Zahid Pervaiz, National College of Business Administration \& Economics ( NCBA \& E ), Lahore, Pakistan. 2013;1-51.

7. Easterly W, Ritzen J, Woolcock M. Social cohesion, institutions, and growth. Econ Polit. 2006;18(2):103-20.

8. McCracken MC. Social Cohesion and Macroeconomic Performance. Econ Implic Soc Cohes. 2016;

9. Richard T. Schaefer. Sociology - A Brief Introduction. 10th ed. New York: McGraw-Hill; 2013.

10. Max Weber. The Theory of Social and Economic Organization. Bur Key concepts Polit Sci. 1970;157.

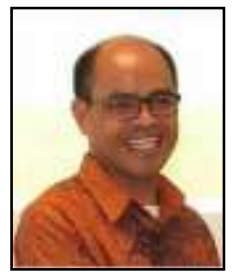

\section{AUTHORS PROFILE}

Yustinus Suhardi Ruman was born in Nara, West Manggarai, Flores, East Nusa Tenggara Province, Indonesia 22 April 1971. He graduated from undergraduate in philosophy at the School of Philosophy St. Paul, Maumere, Flores, East Nusa Tenggarai in 1996. He pursued the study of industrial sociology at the University of Indonesia and completed in 2003. He received a doctoral degree at the University of Indonesia in the field of political sociology in 2015, with a dissertation entitled Exclusion and Inclusion in the Legislative Process Budget Revenue and Expenditure in West Manggarai regency, East Nusa Tenggara.

He joined Bina Nusantara University at Character Building Development Center (CBDC) since 2006 as Subject Content Specialist (SCS), and then in 2012, he was promoted as the Subject Content Coordinator (SCC) with the main responsibility of ensuring the educational material of Character Building in Bina Nusantara University. $\mathrm{He}$ is in charge of the teaching and learning process, both in the classroom and outside the classroom functioning well by the vision and mission achievement of Bina Nusantara University.

Other activities in addition to teaching and teaching Character Building at Bina Nusantara University, $\mathrm{He}$ is also active in providing training to the students of secondary schools, parents and teachers who are the partners of Bina Nusantara University in the vicinity of Jakarta. The topics presented related to Educating Children in a Digital Age, Growing and Growing Together Students, Strategy in Encountering National Exam, Become a Teacher in the Digital Age, and so forth. In the field of professional, He is also a professional training instructor for 'Management Interpersonal Conflict' (2015) 